Syntax Literate: Jurnal Ilmiah Indonesia p-ISSN: 2541-0849 e-ISSN: 2548-1398

Vol. 6, No. 10, Oktober 2021

\title{
SISTEM PENDUKUNG KEPUTUSAN PENENTUAN PENERIMA PROGRAM KELUARGA HARAPAN KECAMATAN PALIMANAN DENGAN METODE MULTI-OBJECTIVE OPTIMIZATION ON THE BASIS OF RATIO ANALYSIS
}

\section{Mukidin, Susi Widyastuti}

Sekolah Tinggi Ilmu Komputer (STIKOM) Poltek Cirebon, Indonesia

Email: mukis.aditya@gmail.com, miss_siwy@yahoo.com

\begin{abstract}
Abstrak
Penelitian ini meneliti tentang bagaimana merancang suatu aplikasi untuk pemerintahan kecamatan guna memudahkan dalam proses penentuan penerima bantuan Program Keluarga Harapan. Dengan adanya aplikasi tersebut, diharapkan nantinya memudahkan bagi pemerintahan Kecamatan guna penentuan penerima bantuan PKH agar lebih akurat dan tepat sasaran. Dengan adanya data yang akurat dan tepat sasaran akan dapat meminimalisisir waktu yang terbuang dalam survey lapangan dan dapat menggunakan sistem yang tengah dirancang ini. Sehingga dapat meningkatkan keakuratan dalam penentuan penerima bantuan dan tidak salah sasaran. Kecamatan Palimanan Kabupaten Cirebon masih mengalami beberapa kendala dan permasalahan dalam penentuan penerima beberapa bantuan yang telah diberkan oleh pemerintahan pusat, salah satunya adalah Program Keluarga Harapan (PKH). Yaitu, pihak perangkat harus melakukan survey langsung dalam penentuan siapa saja yang layak atau tidak mendapatkan bantuan sesuai dengan data yang telah diberikan dari Dinas Sosial. Data yang tercatat di Kantor Kecamatan pun masih menggunakan kertas yang sangat rawan hilang, basah bahkan terbakar. Oleh karena itu diperlukan suatu sistem atau aplikasi yang memudahkan pegawai kecamatan dalam mementukan siapa siapa saja penerima bantuan program keluarga harapan.
\end{abstract}

Kata Kunci: sistem pendukung keputusan; program keluarga harapan; MOORA; PHP; Mysql

\section{Abstract}

This research examines how to design applications for sub-district governments to facilitate the process of determining the beneficiaries of the Education Field of Hope Family Program. With the existence of the application, it is hoped that it will make it more accurate and on target. With the existence of accurate and targeted data, it will be able to minimize the time spent in field surveys and can use the system being designed. So that it can increase the accuracy of determining the recipient of aid and not being misdirected. Palimanan Subdistrict, Cirebon Regency is still experiencing some obstacles and problems in determining the recipient of assistance that has been given by the central government, which is the Hope Family Program (PKH). Namely, the device must be a direct survey in

$\begin{array}{ll}\text { How to cite: } & \text { Mukidin, M. \& Widyastuti, S., (2021) Sistem Pendukung Keputusan Penentuan Penerima Program } \\ & \text { Keluarga Harapan Kecamatan Palimanan dengan Metode Multi-Objective Optimization On The Basis of } \\ & \text { Ratio Analysis. Syntax Literate: Jurnal Ilmiah Indonesia, 6(10). http://dx.doi.org/10.36418/ Syntax- } \\ & \text { Literate.v6i10.4362 } \\ & 2548-1398 \\ \text { E-ISSN: } & \text { Ridwan Institute }\end{array}$


determining who is eligible for the data provided by the Social Service. Data recorded at the District Office still uses paper that is very vulnerable to being lost, wet and even burning. The system or application is needed that makes it easier for sub-district employees to determine who are the recipients of the hopeful family program.

Keywords: Decision Support System; Hope Family Program; MOORA; PHP; Mysql

Received: 2021-09-20; Accepted: 2021-10-05; Published: 2021-10-20

\section{Pendahuluan}

Program Keluarga Harapan (PKH) merupakan salah satu program pemerintah untuk mengembangkan sistem perlindungan sosial terhadap keluarga miskin di Indonesia. Program ini memberikan bantuan uang tunai kepada Rumah Tangga Sangat Miskin (RTSM) dengan catatan mengikuti persyaratan yang terkait dengan peningkatan kualitas Sumber Daya Manusia (SDM) yaitu perlindungan sosial untuk meningkatkan kesejahteraan keluarga bidang Kesehatan dan Pendidikan bagi keluarga yang kurang sejahtera seperti ibu hamil, ibu menyusui, memiliki anak balita dan anak usia sekolah setingkat SD-SMP. Penerima bantuan ini adalah ibu atau wanita dewasa yang mengurus anak pada rumah tangga yang kurang sejahtera.

Kemiskinan menjadi salah satu masalah bagi pemerintah Indonesia. Indonesia merupakan salah satu dari sakian banyak negara berkembang. Sebagai negara berkembang permasalahan klasik yang sering dihadapi adalah masih tingginya angka kemiskinan. Kemiskinan menjadi masalah yang sangat penting karena berdampak buruk terhadap beberapa aspek kehidupan seperti kelaparan, putus sekolah, kesehatan yang memburuk, kriminalitas bahkan sampai kematian. Dengan kondisi seperti itu, maka pemerintah Indonesia perlu membuat suatu program guna mengurangi angka kemiskinan di negara ini (Rhamadani, 2021).

Menurut Badan Pusat Statistik (BPS), pada bulan Maret 2018 jumlah penduduk miskin di Indonesia mencapai 28,59 juta orang (11,22\%), mengalami penambahan sebesar 0,86 juta orang dibanding bulan September 2018 (Badan Pusat Statistik, 2021), tidak terkecuali kemiskinan yang ada di Kabupaten Cirebon khususnya Kecamatan Palimanan.

Tahun 2015, tingkat kemiskinan Cirebon mencapai 87,46\%, mengalami penurunan di tahun 2016 mencapai $0,30 \%$ atau menjadi $87,17 \%$ kemudian di tahun 2017 mengalami kenaikan sebanyak 0,03\% atau menjadi 87,20\% Kondisi angka ini masih dinyatakan tinggi, saat ini ada 382.125 ribu warga yang harus diselamatkan dari kemiskinan (Badan Pusat Statistik Kabupaten Cirebon, 2018)

Pemerintah selaku Policy Maker tentu menggunakan kewajibannya untuk membuat sebuah kebijakan sebagai upaya mengentaskan kemiskinan. Salah satu kebijakan pemerintah yang memberi dampak positif dan masih terus di kembangkan oleh Pemerintah Indonesia adalah Program Keluarga Harapan (PKH). 
Sistem Pendukung Keputusan Penentuan Penerima Program Keluarga Harapan Kecamatan Palimanan dengan Metode Multi-Objective Optimization On The Basis of Ratio Analysis

Menurut Peraturan Menteri Sosial Republik Indonesia No. 1 tahun 2018 tentang Program Keluarga Harapan, Progran Keluarga Harapan merupakan bantuan dari pemerintah berupa uang tunai yang akan diberikan kepada rumah tangga sangat miskin (RTSM) dan sebagai imbalannya RTSM wajib menyekolahkan anaknya dengan prosentase kehadiran minimal $85 \%$ setiap bulan dan melakukan pemerikasaan kesehatan secara berkala (Kementerian Sosial, 2018).

Saat ini banyak Program Keluarga Harapan (PKH) yang dinilai tidak tepat sasaran, dimana masih banyak orang yang seharusnya berhak, justru tidak mendapatkan dana bantuan tersebut. Hal ini berdampak ada subjektifitas di dalam penentuan peserta Program Keluarga Harapan (PKH), terutama jika beberapa calon peserta yang miskin atau kurang mampu memiliki tingkat kelayakan yang tidak jauh berbeda. Dalam hal ini sistem pendataan masih menggunakan data lama yang belum ter update sedangkan setiap tahun penduduk selalu mengalami perubahan pola status sosial dan pengolahan data masih secara manual (Pertiwi et al., 2019).

Berdasarkan hasil wawancara dengan salah satu pendamping lapangan program PKH di Kecamatan Palimanan, selama ini data yang digunakan PKH dari BPS tidak up to date, data yang digunakan untuk menentukan penerima PKH tahun 2018 menggunakan data tahun 2015 sehingga menyebabkan masih banyak warga yang tergolong sangat miskin tidak mendapat bantuan PKH sedangkan warga yang bukan tergolong warga sangat miskin justru mendapatkan bantuan PKH. Untuk mengatasi hal tersebut Pendamping lapangan bersama Pemda setempat berusaha memfilter peserta penerima $\mathrm{PKH}$, proses penentuan warga yang tervalidasi untuk menjadi penerima bantuan PKH sudah memiliki kriteria namun kaidah pendukung keputusan yang digunakan Pendamping lapangan belum ada ketentuan dalam menentukan batasan nilai dari kriteria yang dimiliki. kriteria tersebut akan dijadikan acuan dalam menentukan keluarga yang berhak menerima PKH, namun ketika proses penilaian belum memiliki konsistensi terhadap pemberian bobot dari setiap kriteria dalam menentukan RTSM.

Dengan kondisi seperti itu, maka perlu adanya suatu sistem keputusan dengan metode yang dapat menyelesaikan permasalahan RTSM di atas. Banyak metode sistem keputusan yang bisa digunakan di antaranya adalah metode Multi-Objective Optimization On The Basis Of Ratio Analysis (MOORA).

\section{Metode Penelitian}

Metode penelitian yang digunakan dalam penelitian ini adalah metode penelitian deskriptif. Penelitian deskriptif bertujuan untuk membuat deskripsi sistematis, faktual, dan akurat tentang fakta-fakta dan sifat-sifat populasi daerah tertentu (Utami et al., 2007).

Metode MOORA adalah metode yang diperkenalkan oleh (Revi et al., 2018). Metode yang relatif baru ini pertama kali digunakan oleh Brauers (2003) dalam suatu pengambilan dengan multi-kriteria. Metode MOORA banyak diaplikasikan dalam beberapa bidang seperti bidang manajemen, bangunan, kontraktor, desain jalan, dan ekonomi. Metode ini memiliki tingkat selektifitas yang baik dalam menentukan suatu 
Peserta. Pendekatan yang dilakukan MOORA didefinisikan sebagai suatu proses secara bersamaan guna mengoptimalkan dua atau lebih yang saling bertentangan pada beberapa kendala (Olivianita et al., 2016).

Secara umum metode MOORA meliputi langkah-langkah sebagai berikut:

1. Penentuan nilai matrik Menentukan Tujuan untuk mengindentifikasi atribut evaluasi yang bersangkutan

2. Normalisasi matriks Mewakilkan semua informasi yang tersedia untuk setiap atrribut dalam bentuk matriks keputusan

$\boldsymbol{X}=\left[\begin{array}{ccccc}x_{11} & \ldots & x_{1 i} & \ldots & x_{1 n} \\ \vdots & \ddots & \vdots & \ddots & \vdots \\ \vdots & \ddots & \vdots & \ddots & \vdots \\ x_{i 1} & \ldots & x_{i j} & \ldots & x_{j n} \\ \vdots & \ddots & \vdots & \ddots & \vdots \\ x_{m 1} & \ldots & x_{m i} & \ldots & x_{m n}\end{array}\right]$

3. Normalisasi matriks (Mesran et al., 2018) menyimpulkan bahwa untuk penyebut, pilihan terbaik adalah akar kuadrat dari jumlah kuadrat dan setiap Peserta peratribut.

$$
X^{*}{ }_{i j}=\frac{x_{i j}}{\sqrt{\left[\sum_{\mathrm{j}=1}^{\mathrm{m}} x_{\mathrm{ij}}^{2}\right]}}
$$

4. Mengoptimalkan Atribut Untuk optimasi Multiobjektif, ukuran yang dinormalisasi ditambahkan dalam kasus maksimasi (untuk atribut yang menguntungkan) dan dikurangi dalam kasus minimasi (untuk atribut yang tidak menguntungkan).

$$
y_{j}^{*}=\sum_{i=1}^{i=g} x_{i j}^{*}-\sum_{i=g+1}^{i=n} x_{i j}^{*}
$$

5. Dimana $\mathrm{G}$ adalah jumlah atribut yang akan dimaksimalkan, (n-g) adalah jumlah atribut yang akan diminimalkan, dan yi adalah nilai penilaian yang telah dinormalisasikan dari altenatif 1 terhadap semua atribut. Saat atribut bobot dioertimbangkan, persamaan 3 menjadi sebagai berikut:

$$
y_{i}=\sum_{j=1}^{g} w_{j} x_{i j}^{*}-\sum_{j=g+1}^{n} w_{j} x_{i j}^{*}
$$

Perangkingan nilai Y Nilai Yi bisa positif atau negatif tergantung dari total maksimal dan minimal dalam matriks keputusan. Sebuah urutan peringkat dan Yi menujukan pilihan terakhir. Peserta terbaik memiliki nilai Yi tertinggi, sedangkan Peserta terburuk memiliki nilai yang rendah. 
Sistem Pendukung Keputusan Penentuan Penerima Program Keluarga Harapan Kecamatan Palimanan dengan Metode Multi-Objective Optimization On The Basis of Ratio Analysis

\section{Hasil dan Pembahasan}

\section{Tabel 1}

Bobot Kriteria

\begin{tabular}{|c|c|c|c|c|}
\hline No & Insial & Kriteria & Jenis & Bobot \\
\hline 1 & $\mathrm{C} 1$ & $\begin{array}{l}\text { Luas lantai bangunan (per } \\
\text { orang) }\end{array}$ & Cost & 0.2 \\
\hline 2 & $\mathrm{C} 2$ & Jenis lantai rumah terluas & Cost & 0.2 \\
\hline 3 & $\mathrm{C} 3$ & Jenis dinding rumah terluas & Cost & 0.1 \\
\hline 4 & $\mathrm{C} 4$ & Status Kepemilikan Rumah & Benefit & 0.09 \\
\hline 5 & $\mathrm{C} 5$ & Fasilitas buang air besar & Cost & 0.08 \\
\hline 6 & C6 & Sumber air minum & Cost & 0.07 \\
\hline 7 & $\mathrm{C} 7$ & Sumber penerangan rumah & Cost & 0.06 \\
\hline 8 & $\mathrm{C} 8$ & $\begin{array}{l}\text { Jenis Bahan bakar Untuk } \\
\text { Memasak }\end{array}$ & Cost & 0.05 \\
\hline 9 & C9 & Konsusmi sumber protein & Cost & 0.04 \\
\hline 10 & $\mathrm{C} 10$ & Pembelian 1 setel baju & Cost & 0.03 \\
\hline 11 & $\mathrm{C} 11$ & Makan dalam 1 hari & Cost & 0.02 \\
\hline 12 & C12 & $\begin{array}{l}\text { Kemampuan memabayar } \\
\text { biaya pengobatan }\end{array}$ & Cost & 0.01 \\
\hline 13 & $\mathrm{C} 13$ & $\begin{array}{l}\text { Penghasilan Kepala } \\
\text { Keluarga }\end{array}$ & Cost & 0.01 \\
\hline 14 & C14 & $\begin{array}{l}\text { Jumlah Peserta KK/Rumah } \\
\text { Tangga }\end{array}$ & Benfit & 0.01 \\
\hline 15 & $\mathrm{C} 15$ & $\begin{array}{l}\text { Pendidikan Tertinggi } \\
\text { Kepala Keluarga }\end{array}$ & Cost & 0.01 \\
\hline 16 & C16 & $\begin{array}{l}\text { Kepemilikan } \\
\text { Tabungan/barang yang } \\
\text { mudah dijual }\end{array}$ & Cost & 0.01 \\
\hline al Bobot & & & & 1 \\
\hline
\end{tabular}

\section{Tabel 2}

Bobot sub kriteria Luas lantai bangunan (per orang)

\begin{tabular}{c|cc}
\hline No & \multicolumn{1}{|c}{ Sub Kriteria } & Bobot \\
\hline 1 & lebih dari $16 \mathrm{~m} 2$ & 10 \\
\hline 2 & $13-16 \mathrm{~m} 2$ & 15 \\
\hline 3 & $8-12 \mathrm{~m} 2$ & 25 \\
\hline 4 & Kurang $8 \mathrm{~m} 2$ & 50 \\
\hline
\end{tabular}

Tabel 3

Bobot sub kriteria Jenis lantai rumah terluas

\begin{tabular}{clc}
\hline No & \multicolumn{1}{c}{ Sub Kriteria } & Bobot \\
\hline 1 & Granit & 10 \\
\hline 2 & $\begin{array}{l}\text { Keramik/Ubin/tegel/tera } \\
\text { so }\end{array}$ & 15 \\
\hline 3 & Semen/tegel batu putih & 25 \\
\hline 4 & Tanah & 50 \\
\hline
\end{tabular}


Tabel 4

Bobot sub kriteria Jenis dinding rumah terluas

\begin{tabular}{clc}
\hline No & \multicolumn{1}{c}{ Sub Kriteria } & Bobot \\
\hline 1 & $\begin{array}{l}\text { Tembok plesteran/Kayu } \\
\text { kualitas tinggi }\end{array}$ & 10 \\
\hline 2 & Tembok tanpa plesteran & 15 \\
\hline 3 & $\begin{array}{l}\text { Plesteran anyaman } \\
\text { bambu/kawat/kalsibord }\end{array}$ & 20 \\
\hline 4 & $\begin{array}{l}\text { Kayu kualitas } \\
\text { rendah/Kalsibord }\end{array}$ & 25 \\
\hline 5 & Anyaman bamboo & 30 \\
\hline \hline
\end{tabular}

Tabel 5

Bobot sub kriteria Jenis dinding rumah terluas

\begin{tabular}{clc}
\hline No & Sub Kriteria & Bobot \\
\hline 1 & Milik Sendiri & 20 \\
\hline 2 & Bebas Sewa & 30 \\
\hline 3 & Sewa & 50 \\
\hline
\end{tabular}

Tabel 6

Bobot sub kriteria Fasilitas buang air besar

\begin{tabular}{clc}
\hline No & \multicolumn{1}{c}{ Sub Kriteria } & Bobot \\
\hline 1 & Leher angsa & 10 \\
\hline 2 & Plengsengan & 15 \\
\hline 3 & Bersama / WC Umum & 25 \\
\hline 4 & Cemplung/cubluk & 50 \\
\hline
\end{tabular}

Tabel 7

Bobot sub kriteria Sumber air minum

\begin{tabular}{clc}
\hline No & \multicolumn{1}{c}{ Sub Kriteria } & Bobot \\
\hline 1 & Air kemasan bermerk & 2 \\
\hline 2 & Air isi ulang & 3 \\
\hline 3 & Ledeng meteran & 4 \\
\hline 4 & Sumur bor/pompa/Sumur terlindung & 6 \\
\hline 5 & Sumur tak terlindung & 10 \\
\hline 6 & Mata air terlindung & 15 \\
\hline 7 & Air hujan/PAH & 25 \\
\hline 8 & $\begin{array}{l}\text { Mata air tak terlindung/Air } \\
\text { sungai/danau/waduk' }\end{array}$ & 35 \\
\hline
\end{tabular}


Sistem Pendukung Keputusan Penentuan Penerima Program Keluarga Harapan Kecamatan Palimanan dengan Metode Multi-Objective Optimization On The Basis of Ratio Analysis

Tabel 8

Bobot sub kriteria Sumber penerangan rumah

\begin{tabular}{clc}
\hline No & \multicolumn{1}{c}{ Sub Kriteria } & Bobot \\
\hline 1 & 1200 VA atau lebih & 10 \\
\hline 2 & $\begin{array}{l}\text { listrik non PLN (solar } \\
\text { cell/genset/biogas) }\end{array}$ & 15 \\
\hline 3 & $900 \mathrm{VA}$ & 20 \\
\hline 4 & $450 \mathrm{VA}$ & 25 \\
\hline 5 & Tanpa listrik & 30 \\
\hline
\end{tabular}

Tabel 9

Bobot sub kriteria Jenis bahan bakar untuk memasak

\begin{tabular}{ccc}
\hline No & Sub Kriteria & Bobot \\
\hline 1 & Gas $>3 \mathrm{~kg}$ & 20 \\
\hline 2 & Gas $3 \mathrm{~kg}$ & 30 \\
\hline 3 & Kayu bakar / Arang & 50 \\
\hline
\end{tabular}

Tabel 10

Bobot sub kriteria Sumber protein dalam 1 minggu

\begin{tabular}{clc}
\hline No & Sub Kriteria & Bobot \\
\hline 1 & Daging & 20 \\
\hline 2 & Susu & 30 \\
\hline 3 & Ayam & 50 \\
\hline
\end{tabular}

Tabel 11

Bobot sub kriteria Pembelian 1 setel pakain dalam 1 tahun

\begin{tabular}{ccc}
\hline No & Sub Kriteria & Bobot \\
\hline 1 & 1 Setel pakaian & 75 \\
\hline 2 & $>$ 1 setel pakaian & 25 \\
\hline
\end{tabular}

Tabel 12

Bobot sub kriteria Kemampuan membayar biaya pengobatan

\begin{tabular}{clc}
\hline No & Sub Kriteria & Bobot \\
\hline 1 & Puskesmas & 75 \\
\hline 2 & Poliklinik & 25 \\
\hline
\end{tabular}

Tabel 13

Bobot sub kriteria Penghasilan Kepala Keluarga

\begin{tabular}{ccc}
\hline No & Sub Kriteria & Bobot \\
\hline 1 & $\begin{array}{c}\text { Rp. } 600.000,- \text { per } \\
\text { bulan }\end{array}$ & 75 \\
\hline 2 & $\begin{array}{c}>\text { Rp. } 600.000,- \text { per } \\
\text { bulan }\end{array}$ & 25 \\
\hline
\end{tabular}


Tabel 14

Bobot sub kriteria Jumlah Peserta KK/Keluarga

\begin{tabular}{clc}
\hline No & \multicolumn{1}{c}{ Sub Kriteria } & Bobot \\
\hline 1 & $1-3$ orang & 10 \\
\hline 2 & 4 orang & 15 \\
\hline 3 & 5 orang & 25 \\
\hline 4 & $\begin{array}{l}\text { Lebih dari 6 oranag atau } \\
\text { lansia sebatangkara }\end{array}$ & 50 \\
\hline
\end{tabular}

Tabel 15

Bobot sub kriteria Pendidikan tertinggi kepala keluarga

\begin{tabular}{clc}
\hline No & \multicolumn{1}{c}{ Sub Kriteria } & Bobot \\
\hline 1 & Sarjana & 4 \\
\hline 2 & Diploma & 6 \\
\hline 3 & $\begin{array}{l}\text { SMA/SMK/SMALB/Paket } \\
\text { C/M Aliyah }\end{array}$ & 10 \\
\hline 4 & $\begin{array}{l}\text { SMP/SMPLB/Paket B/M } \\
\text { Tsanawiyah }\end{array}$ & 20 \\
\hline 5 & $\begin{array}{l}\text { SD/SDLB/Paket A/M } \\
\text { Ibtidaiyah }\end{array}$ & 25 \\
\hline 6 & $\begin{array}{l}\text { Tidak sekolah/Tidak } \\
\text { Tamat SD Sederatat }\end{array}$ & 35 \\
\hline
\end{tabular}

Tabel 16

Bobot sub kriteria Kepemilikan tabungan/barang yang mudah dijual

\begin{tabular}{clc}
\hline No & \multicolumn{1}{c}{ Sub Kriteria } & Bobot \\
\hline 1 & $\begin{array}{l}\text { Emas }>9 \text { gram dan } \\
\text { Uang/Tabungan }>5 \text { Juta }\end{array}$ & 10 \\
\hline 2 & Uang/Tabungan > 5 Juta & 15 \\
\hline 3 & Emas < 9 gram & 25 \\
\hline 4 & Tidak Memiliki & 50 \\
\hline
\end{tabular}

Tabel 17

Bobot sub kriteria Makan dalam 1 hari

\begin{tabular}{clc}
\hline No & Sub Kriteria & Bobot \\
\hline 1 & 4 kali sehari & 10 \\
\hline 2 & 3 kali sehari & 15 \\
\hline 3 & 2 kali sehari & 25 \\
\hline 4 & 1 hari sekali & 50 \\
\hline
\end{tabular}

A. Normalisasi Matrik

1. Kriteria $\mathbf{C 1}=\sqrt{\mathbf{5 0}} \mathbf{0}^{2}+\mathbf{5 0}^{2}+\mathbf{2 0}^{2}=\mathbf{7 3 . 4 8}$

$\mathrm{A}_{11}=50 / 73.48=0.68$

$\mathrm{A}_{12}=50 / 73.48=0.68$

$\mathrm{A}_{13}=20 / 73.48=0.27$

2. Kriteria $\mathbf{C 2}=\sqrt{50^{2}}+\mathbf{3 0}^{2}+\mathbf{1 0}^{2}=\mathbf{5 9 . 1 6}$

$\mathrm{A}_{21}=50 / 59.16=0.84$

$\mathrm{A}_{22}=30 / 59.16=0.50$ 
Sistem Pendukung Keputusan Penentuan Penerima Program Keluarga Harapan Kecamatan Palimanan dengan Metode Multi-Objective Optimization On The Basis of

$$
\mathrm{A}_{23}=10 / 59.16=0.16
$$

3. Kriteria $\mathrm{C3}=\sqrt{ } \mathbf{3 0}^{2}+\mathbf{2 0}^{2}+20^{2}=41.23$

$$
\begin{aligned}
& \mathrm{A}_{31}=30 / 41.23=0.72 \\
& \mathrm{~A}_{32}=20 / 41.23=0.48 \\
& \mathrm{~A}_{33}=20 / 41.23=0.48
\end{aligned}
$$

4. Kriteria $\mathbf{C 4}=\sqrt{50^{2}}+\mathbf{1 0}^{2}+\mathbf{1 0}^{2}=\mathbf{5 1 . 9 6}$

$$
\begin{aligned}
& \mathrm{A}_{41}=50 / 51.96=0.96 \\
& \mathrm{~A}_{42}=10 / 51.96=0.19 \\
& \mathrm{~A}_{43}=10 / 51.96=0.19
\end{aligned}
$$

5. Kriteria $\mathrm{C} 5=\sqrt{35^{2}}+20^{2}+20^{2}=45$

$$
\begin{aligned}
& A_{51}=35 / 0.45=0.77 \\
& A_{52}=20 / 0.45=0.44 \\
& A_{53}=20 / 0.45=0.44
\end{aligned}
$$

6. Kriteria $\mathbf{C 6}=\sqrt{30^{2}}+\mathbf{3 0}^{2}+\mathbf{3 0}^{2}=\mathbf{4 6 . 9 0}$

$$
\begin{aligned}
& \mathrm{A}_{61}=30 / 46.90=0.63 \\
& \mathrm{~A}_{62}=30 / 46.90=0.63 \\
& \mathrm{~A}_{63}=30 / 46.90=0.63
\end{aligned}
$$

7. Kriteria $\mathbf{C} 7=\sqrt{50^{2}}+\mathbf{5 0} 0^{2}+\mathbf{5 0}^{2}=\mathbf{8 6 . 6 0}$

$$
\begin{aligned}
& A_{71}=50 / 86.60=0.57 \\
& A_{72}=50 / 86.60=0.57 \\
& A_{73}=50 / 86.60=0.57
\end{aligned}
$$

8. Kriteria $\mathbf{C 8}=\sqrt{50^{2}}+\mathbf{5 0}^{2}+\mathbf{5 0}^{2}=\mathbf{8 6 . 6 0}$

$$
\begin{aligned}
& A_{81}=50 / 86.60=0.57 \\
& A_{82}=50 / 86.60=0.57 \\
& A_{83}=50 / 86.60=0.57
\end{aligned}
$$

9. Kriteria $\mathbf{C 9}=\sqrt{75^{2}}+\mathbf{7 5}^{2}+\mathbf{7 5}^{2}=\mathbf{1 2 9 . 9 0}$

$$
\begin{aligned}
& A_{91}=75 / 129.90=0.57 \\
& A_{92}=75 / 129.90=0.57 \\
& A_{93}=75 / 129.90=0.57
\end{aligned}
$$

10. Kriteria $\mathbf{C 1 0}=\sqrt{752}+\mathbf{7 5 2}+\mathbf{7 5 2}=\mathbf{1 2 9 . 9 0}$

$$
\begin{aligned}
& \mathrm{A}_{101}=75 / 129.90=0.57 \\
& \mathrm{~A}_{102}=75 / 129.90=0.57 \\
& \mathrm{~A}_{103}=75 / 129.90=0.57
\end{aligned}
$$

11. Kriteria $\mathrm{C} 11=\sqrt{75^{2}}+75^{2}+75^{2}=129.90$

$$
\begin{aligned}
& \mathrm{A}_{111}=75 / 129.90=0.57 \\
& \mathrm{~A}_{112}=75 / 129.90=0.57 \\
& \mathrm{~A}_{113}=75 / 129.90=0.57
\end{aligned}
$$

12. Kriteria $\mathrm{C} 12=\sqrt{25^{2}}+25^{2}+25^{2}=43.30$

$$
\begin{aligned}
& A_{121}=25 / 43.30=0.57 \\
& A_{122}=25 / 43.30=0.57 \\
& A_{123}=25 / 43.30=0.57
\end{aligned}
$$

13. Kriteria $\mathrm{C} 13=\sqrt{35^{2}}+35^{2}+35^{2}=60.62$ 


$$
\begin{aligned}
& \mathrm{A}_{131}=35 / 60.62=0.57 \\
& \mathrm{~A}_{132}=35 / 60.62=0.57 \\
& \mathrm{~A}_{133}=35 / 60.62=0.57
\end{aligned}
$$

14. Kriteria $\mathbf{C 1 4}=\sqrt{\mathbf{5} 0^{2}}+\mathbf{5 0} 0^{2}+\mathbf{5 0} 0^{2}=\mathbf{8 6 . 6 0}$

$$
\begin{aligned}
& A_{141}=50 / 86.60=0.57 \\
& A_{142}=50 / 86.60=0.57 \\
& A_{143}=50 / 86.60=0.57
\end{aligned}
$$

15. Kriteria $\mathrm{C15}=\sqrt{10^{2}}+20^{2}+35^{2}=41.53$

$$
\begin{aligned}
& \mathrm{A}_{141}=10 / 41.53=0.24 \\
& \mathrm{~A}_{142}=20 / 41.53=0.48 \\
& \mathrm{~A}_{143}=35 / 41.53=0.48
\end{aligned}
$$

16. Kriteria $\mathrm{C} 16=\sqrt{ } \mathbf{2 5}^{2}+\mathbf{2 5}^{2}+\mathbf{5 0}^{2}=\mathbf{6 1 . 2 3}$

$$
\begin{aligned}
& A_{141}=25 / 61.23=0.40 \\
& A_{142}=25 / 61.23=0.40 \\
& A_{143}=50 / 61.23=0.81
\end{aligned}
$$

\section{B. Menghitung Nilai Y}

\section{Tabel 18}

Tabel Hitung Nilai Y

\begin{tabular}{llccc}
\hline No & Peserta & $\begin{array}{c}\text { Max } \\
(\mathbf{C 4 + C 1 4})\end{array}$ & $\begin{array}{c}\text { Min } \\
(\mathbf{C 1 + C 1 2 + C 3 + C 5 + C 6 +}+ \\
\text { C7+C8+C9+C10+C11+ }\end{array}$ & $\begin{array}{c}\text { Min } \\
\text { C12+C13+C15+C16) }\end{array}$ \\
& & & 0.619 & -0.52 \\
& & & & -0.50 \\
\hline 1 & $\begin{array}{l}\text { Bambang } \\
\text { Irawan }\end{array}$ & 0.092 & 0.503 & -0.34 \\
\hline 2 & Bunaya & 0.023 & 0.362 & \\
\hline 3 & Maiyani & 0.023 & &
\end{tabular}

Dari hasil di atas, dapat dilihat rangking setiap alternative dari perhitungan kriteria setiap calon peserta PKH pada table berikut:

\section{Tabel 19}

Tabel Hasil Perangkingan

\begin{tabular}{clcc}
\hline No & Peserta & Hasil & Rangking \\
\hline 1 & Maiyani & -0.34 & 1 \\
\hline 2 & Bunaya & -0.50 & 2 \\
\hline 3 & Bambang & -0.52 & 3 \\
& Irawan & & \\
\hline
\end{tabular}


Sistem Pendukung Keputusan Penentuan Penerima Program Keluarga Harapan Kecamatan Palimanan dengan Metode Multi-Objective Optimization On The Basis of Ratio Analysis

\section{Desain Interface}

\section{a. Halaman Login}

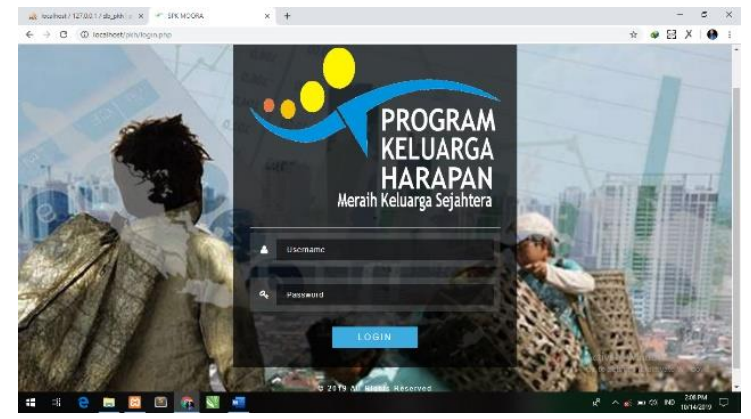

Gambar 1

Halaman Login

b. Halaman Dashboard

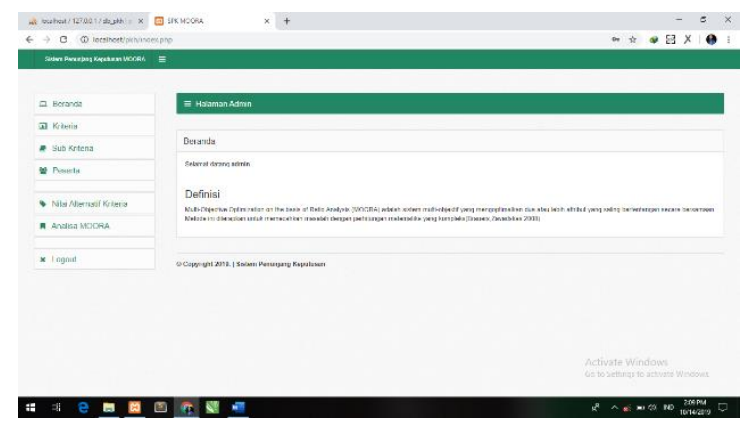

Gambar 2

Halaman Dashboard

c. Halaman Halaman Kriteria

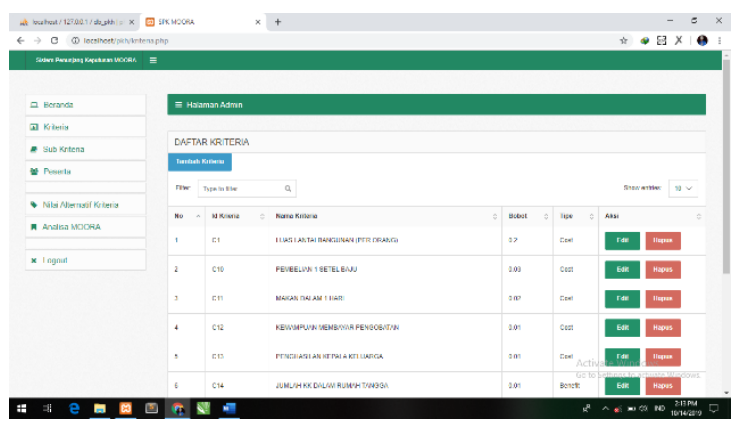

Gambar 3

Halaman Krieria 
Mukidin, Susi Widyastuti

d. Halaman Sub Kriteria

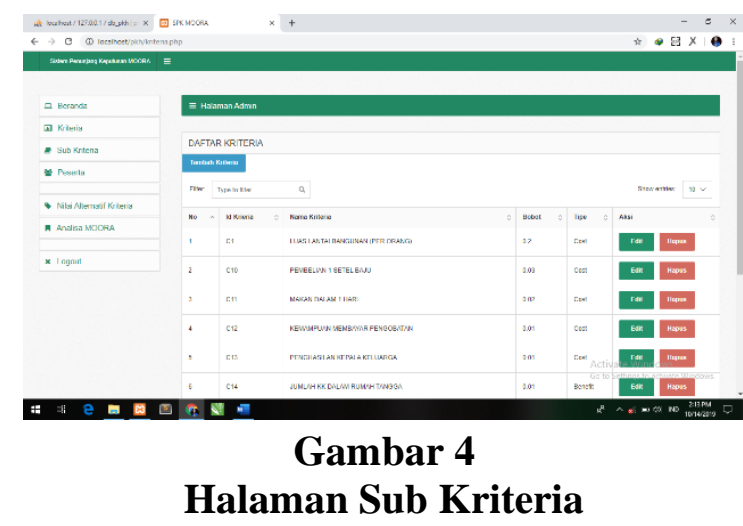

e. Halaman Peserta

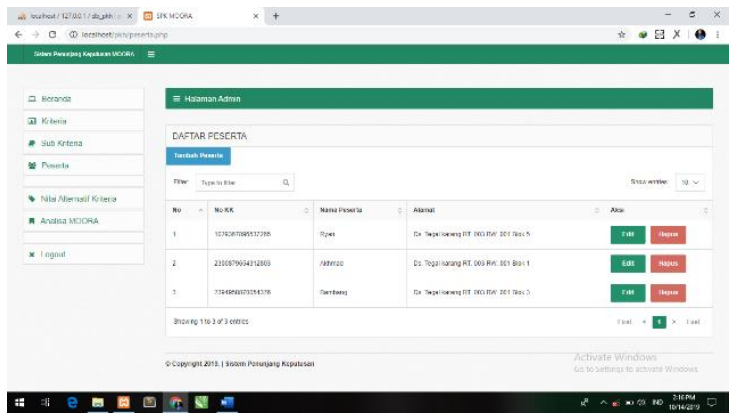

Gambar 5

Halaman Peserta

f. Halaman Nilai Peserta

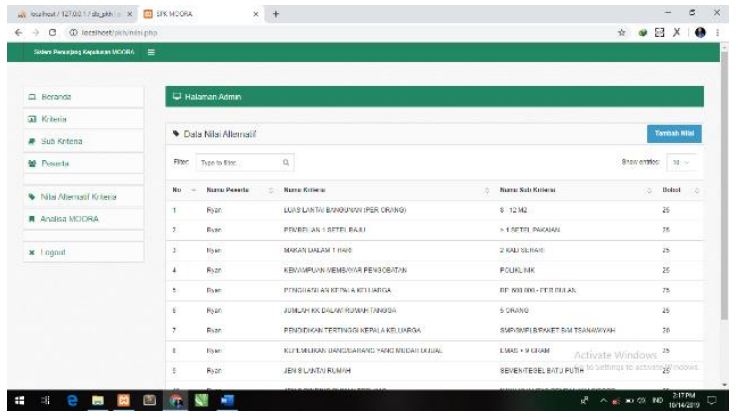

Gambar 6

Halaman Nilai Peserta 
Sistem Pendukung Keputusan Penentuan Penerima Program Keluarga Harapan Kecamatan Palimanan dengan Metode Multi-Objective Optimization On The Basis of Ratio Analysis

\section{g. Halaman Proses MOORA}

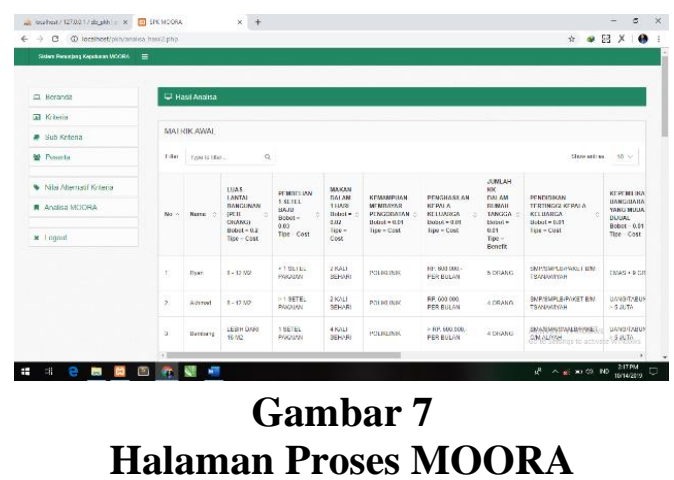

Pengujian yang dilakukan penulis (pengembang sistem) terhadap unjuk kerja sistem pendukung keputusan penentuan penerima program keluarga harapan kecamatan palimanan dengan metode multi-objective optimization on the basis of ratio analysis (MOORA) dapat berjalan dengan baik dalam merekomendasikan masayarakat penerima Program Keluarga Harapan.

Berdasarkan pengujian antara sistem dan perhitungan manual, menunjukan bahwa hasailnya sama sehingga dapat dikatakan bahwa sistem dapat berjalan dengan baik sesuai rancangan.

\section{Kesimpulan}

Dari hasil pembahasan tentang perancangan Sistem Pendukung Keputusan Penentuan Penerima Program Keluarga Harapan Kecamatan Palimanan dengan Metode MOORA, maka di ambil kesimpulan: 1). Semua Data yang dikirim oleh BPS kepada pihak PKH akan di olah menggunakan sistem ini sehingga hasil yang di hasilkan akan tepat sasaran dan bisa mengurangi kemiskinan. 2). Sistem Pendukung Keputusan yang digunakan akan lebih efektif dalam penentuan penerima program PKH. 3). Aplikasi yang di hasilkan akan lebih bermanfaat bagi para Pendamping Lapangan untuk kegiatan PKH. 
Mukidin, Susi Widyastuti

\section{BIBLIOGRAFI}

Badan Pusat Statistik. (2021). Berita Resmi Statistik. Bps.Go.Id, 13. Google Scholar

Badan Pusat Statistik Kabupaten Cirebon. (2018). Kabupaten Cirebon Dalam Angka 2018. Badan Pusat Statistik Kabupaten Cirebon. Google Scholar

Firmansyah (2018). Basis Data. Bandung: Informatika. Google Scholar

Hayadi B Herman, R. K. (2016). What Expert System Apa itu Sistem. Yogyakarta: CV. Budi Utama. Google Scholar

Indrajani. (2015). Database Design (Case Study All in One). Jakarta: PT Elex Media. Google Scholar

Kementerian Sosial. (2018). Peraturan Menteri Sosial Republik Indonesia Nomor 1 Tahun 2018 Tentang Program Keluarga Harapan. 2018. Google Scholar

Mesran, M., Pardede, S. D. A., Harahap, A., \& Siahaan, A. P. U. (2018). Sistem Pendukung Keputusan Pemilihan Peserta Jaminan Kesehatan Masyarakat (Jamkesmas) Menerapkan Metode MOORA. Jurnal Media Informatika Budidarma, 2(2). Google Scholar

Olivianita, L., Ekojono, E., \& Ariyanto, R. (2016). Sistem pendukung keputusan kelayakan hasil cetakan buku menggunakan metode moora. Seminar Informatika Aplikatif Polinema. Google Scholar

Pertiwi, I. P., Fedinandus, F., \& Limantara, A. D. (2019). Sistem Pendukung Keputusan Penerima Program Keluarga Harapan (PKH) Menggunakan Metode Simple Additive Weighting. CAHAYAtech, 8(2), 182. https://doi.org/10.47047/ct.v8i2.46. Google Scholar

Revi, A., Parlina, I., \& Wardani, S. (2018). Analisis Perhitungan Metode MOORA dalam Pemilihan Supplier Bahan Bangunan di Toko Megah Gracindo Jaya. InfoTekJar: Jurnal Nasional Informatika Dan Teknologi Jaringan, 3(1), 95-99. Google Scholar

Rhamadani, I. (2021). Analisis Pengaruh Inklusi Keuangan Dan Kemiskinan Di Indonesia (Studi Kasus Pada Tahun 2007-2018). Jurnal Ilmiah Mahasiswa FEB, 10(1). Google Scholar

Rosa, \& Shalahuddin. (2015). Rekayasa Perangkat Lunak Terstruktur. Bandung: Informatika. Google Scholar

Sugiyono. (2017). Metode Penelitian Kuantitatif, Kualitatif, dan R\&D. Bandung: Alfabeta, CV. Google Scholar

Sukamto, R., \& Shalahuddin, M. (2016). Rekayasa Perangkat Lunak. Bandung: 
Sistem Pendukung Keputusan Penentuan Penerima Program Keluarga Harapan Kecamatan Palimanan dengan Metode Multi-Objective Optimization On The Basis of Ratio Analysis

Informatika. Google Scholar

Utami, E., Istiyanto, J. E., \& Raharjo, S. (2007). Metodologi penelitian pada ilmu komputer. Seminar Nasional Teknologi 2007, 2007(November), 1-13. Google Scholar

\section{Copyright holder:}

Mukidin, Susi Widyastuti (2021)

First publication right:

Syntax Literate: Jurnal Ilmiah Indonesia

This article is licensed under:

(c) (i) (?) 